\title{
Chemical analyses of the seeds of some forage legumes from Turkey. A chemotaxonomic approach
}

\author{
By A. Kocak ${ }^{1, *}$, K. Kokten ${ }^{2}$, E. Bagci ${ }^{3}$, M. Akcura ${ }^{2}$, S. Hayta ${ }^{4}$, A. Bakogluand O. Kilic ${ }^{1}$
}

\author{
${ }^{1}$ Bingol University, Art \& Science Faculty, Biology Department, Bingol-Turkey \\ ${ }^{2}$ Bingol University, Agriculture Faculty, Field Crops Department, Bingol-Turkey \\ ${ }^{3}$ Firat University, Art \& Science Faculty, Biology Department, Elazig-Turkey \\ ${ }^{4}$ Bitlis Eren University, Art \& Science Faculty, Biology Department, Bitlis-Turkey \\ ${ }^{5}$ Programme of Field Crops, Collage of Bingol, Bingol-Turkey \\ "Corresponding author: akocak@ bingol.edu.tr
}

\section{RESUMEN}

Análisis químico de semillas de algunas leguminosas forrajeras de Turquía. Un enfoque quimiotaxonómico.

Se han estudiado las semillas procedentes de seis leguminosas forrajeras (leguminosas) en relación a sus proteínas, contenido de taninos y composición de ácidos grasos. El contenido de proteínas de las semillas de leguminosas forrajeras osciló entre un 23,1 y un $37,2 \%$. Por otro lado, el contenido de taninos de las mismas semillas se encontraron entre 0,67 y $6,33 \%$. La composición en ácidos grasos de estas seis especies diferentes se determinó por cromatografía gaseosa como ésteres metílicos de los ácidos grasos. Los aceites de las semillas de diferentes taxones de leguminosas contenían los ácidos linoleico y linolénico como principales componentes. Los aceites de semillas de las especies $\mathrm{He}$ lianthus Lathyrus, Onobrychis crista-galli, Trigonella foenumgraceum, Lotus corniculatus, y Leuceana Leucocephala contienen $50.0,59.4,69.5,37.06$ y $52.6 \%$, respectivamente de ácido linoleico, como principal componente de los ácidos grasos, mientras que el aceite de semillas de Cicer Lathyrus contiene ácido linolénico en un $29,7 \%$ como principal componente de los ácidos grasos. Las proporciones de los ácidos grasos en los géneros de leguminosas resultaron ser muy variable. En el estudio de los taxones, el ácido palmítico se encuentra entre los ácidos grasos saturados más importante, por otro lado los ácidos oleico, linoleico y linolénico se encuentra entre los principales ácidos grasos insaturados.

PALABRAS CLAVE: Aceites de semillas - Ácidos grasos - Leguminosas - Proteínas - Taninos

\section{SUMMARY}

Chemical analyses of the seeds of some forage legumes from Turkey. A chemotaxonomic approach.

The seeds of six forage legumes (Leguminosae) were investigated for their protein, tannin contents and fatty acid compositions. The protein contents of forage legume seeds were found to be between 23.1 and $37.2 \%$. On the other hand, the tannin contents of the same seeds were found to be between 0.67 and $6.33 \%$. The fatty acid compositions of these six different species were determined by gas chromatography of the methyl esters of their fatty acids. The seed oils of different Leguminous taxa contained linoleic and linolenic acids as their major components. The seed oils of Lathyrus annuus, Onobrychis crista-galli, Trigonella foenum-graceum, Lotus corniculatus, and Leuceana leucocephala species contain $50.0,59.4,69.5,37.06$, and $52.6 \%$ linoleic acid, respectively, as the major component fatty acids, whereas in the seed oil of Lathyrus cicer, linolenic acid accounts for $29.7 \%$ as the major component fatty acid. The ratios of these fatty acids in the Leguminous genera were found to be highly variable. In the study of taxa, palmitic acid was found in the major saturated fatty acids, on the other hand oleic, linoleic and linolenic acids were found in major unsaturated fatty acids.

KEY-WORDS: Fatty acid - Leguminosae - Protein Seed oil - Tannin.

\section{INTRODUCTION}

Legumes as source of protein for both forage and grain have a great chance of increasing their importance in the farming systems of the 21st century. Legume plants include many economically important crop plants that are utilized in human foodstuffs, herbal medicines, oil materials and as animal forages.

In Turkey, the Lathyrus species has been cultivated in small field areas and used mainly as forage and rarely as food. The Lathyrus species contains some toxic substances. One of the most important of these substances is a neurotoxinoxalyl diamino propionic acid - (ODAP), which can result in paralysis in humans and the lower limbs of animals by affecting the central nervous system. This disease, named Lathyrism, generally occurs when seeds are consumed in large quantities for 3-4 months (Basaran et al. 2007).

Sainfoin (Onobrychis viciifolia Scop.), also known as holy clover, is a perennial forage legume with a deep taproot often grown in conjunction with forage grasses to reduce bloat hazard as well as to improve soil fertility due to its nitrogen fixing ability. Another desirable trait is that sainfoin has an early growth habit, sprouting earlier than alfalfa in spring to give good forage yields. While the availability of early fresh forage for stock is appreciated by farmers it is the ability of the feed to reduce 
the incidence of bloating and to increase animal performance which provided the main incentive for its incorporation into farm management. Bloating is a major worldwide problem and frequently occurs in dairy cattle affecting up to $90 \%$ of the herds in a single district, causing many deaths (Lu et al. 2000).

Trigonella foenum-graecum is native to the area from the eastern Mediterranean to Central Asia and Ethiopia, and much cultivated in Pakistan, India, and China. Its dried ripe seeds are referred to as Trigonella seeds or as fenugreek and are well known for their pungent aromatic properties. The seeds contain the alkaloid trigonelline along with mucilage, tannic acid, yellow coloring matter, fixed and volatile oils, a bitter extractive, diosgenin, gitogenin, a trace of trigogenin, and vitamin A (Petit et al. 1995). The seeds are also rich in protein and contain a unique major free amino acid 4hydroxyisoleucine, which has been characterized as one of the active ingredients in fenugreek seeds (Broca et al. 1999).

Forages play an important role in ruminant nutrition in terms of providing energy, protein and minerals. Birdsfoot trefoil (Lotus corniculatus) is one of the self-generating plants in native pastures in Turkey. The nutritive value of birdsfoot trefoil was comparable with other legumes (Waghorn and Shelton 1992).

Tree legumes, such as Leuceana leucocephala, have been used as protein supplements for low quality forages and resulted in improved ruminant productivity (Norton 1994). It is reported that in over 26 Leucaena species studied, Leucaena colinsii has the lowest content of condensed tannin (CT) whereas Leucaena pallida has the highest CT content (Dalzell et al. 1998). Condensed tannin has been reported to strongly bind protein and other components in the diet, rendering them unavailable for digestion and absorption, which in turn affects animal performance (Mangan 1988).

Pulses are also important as potential sources of natural tocopherols, tocotrienols and fatty acids all over the world (Krishna et al. 1997; Bagci et al. 2003). Some leguminous species are groundnut (Arachis hypogea), cowpea (Vigna anguiculata), soybean (Glycine max), common bean (Phaseolus vulgaris), pea (Pisum sativum), lentil (Lens culinaris) and broad bean (Vicia faba). Groundnut and soybean have received considerable attention because of their high oil as well as high protein contents. Therefore, their fat characteristics and fatty acid components have been extensively investigated (Grela and Gunter 1995).

The objective of the present study was to determine the tannin and protein contents of the seeds of some forage legumes (Lathyrus annuus L., Lathyrus cicera L., Onobrychis crista-galli (L.) Lam., Trigonella foenum-graceum L., Lotus corniculatus L., and Leuceana leucocephala Lam.). An additional aim was to characterize seed fatty acids used for animals in the field, to establish their nutritional value and determine their potential as renewable resources of FA and other chemical patterns.

\section{MATERIALS AND METHODS}

\subsection{Seed samples}

The Forage legumes used in this study were Lathyrus annuus L., Lathyrus cicera L., Onobrychis crista-galli (L.) Lam., Trigonella foenum-graceum L., Lotus corniculatus L., and Leuceana leucocephala Lam. Matured seeds of these species were collected from various locations in Adana (Turkey) between June and August, 2009.

\subsection{Oil extraction and preparation of fatty acid methyl esters (FAME)}

Impurities were removed from the seeds and the cleaned seeds were ground into powder using a ball mill. Lipids were extracted with hexane/ isopropanol 2v/v (Hara and Radin 1978). The lipid extracts were centrifuged at $10.0 \mathrm{~g}$ for $5 \mathrm{~min}$ and filtered; then the solvent was removed on a rotary evaporator at $40^{\circ} \mathrm{C}$.

\subsection{Capillary GLC}

Fatty acids in the lipid extracts were converted into methyl esters with $2 \%$ sulphuric acid $(\mathrm{v} / \mathrm{v})$ in methanol (Christie 1990). The fatty acid methyl esters were extracted with $n$-hexane. Then the methyl esters were separated and quantified by gas chromatography and flame ionization detection (Schimadzu GC, 17 Ver.3) coupled to a glass GC 10 software computing recorder. Chromatography was performed with a capillary column $(25 \mathrm{~m}$ in length and $0.25 \mathrm{~mm}$ in diameter, Permabound 25, Machery - Nagel, Germany) using nitrogen as the carrier gas (flow rate $0.8 \mathrm{ml} / \mathrm{min}$ ). The temperatures of the column, detector and injector valve were $130-220$ and $240-280^{\circ} \mathrm{C}$, respectively. Identification of the individual fatty acids was made by frequent comparisons with authentic standard mixtures that were analyzed under the same conditions.

\subsection{Determination of protein and tannin contents}

Seed samples were cleaned and their protein content was analyzed according to the method of AOAC (1990). The Tannin contents of the seeds were determined by the method of Makkar et al. (1995). Protein and tannin analyses were carried out in triplicate.

\subsection{Statistical analysis}

The experimental design was a completely randomized design with 3 replicates. Standard analyses of variance (anova) were used to analyze the data obtained. The means of tannin and protein contents were compared by an LSD test using an SAS packet program. 


\section{RESULTS AND DISCUSSION}

In this study, the total protein amount, fatty acid composition and tannin contents of some forage legumes from Turkey were determined. The results of the protein, tannin and fatty acid analyses are shown in Tables 1 and 2.

The protein contents of forage legume species varied from 23.1 to $37.2 \%$ (Table 1 ). Generally, the amount of protein detected was lower in Lathyrus cicera $(23.1 \%)$ and Leuceana leucocephala $(23.9 \%)$ than in Trigonella foenum-graceum $(24.8 \%)$ and Lathyrus annuus (26.1\%). The protein content of Leuceana was similar to the value reported by Abdulrazak et al. (2006). The highest protein contents were found to be 34.0 and $37.2 \%$ in Lotus corniculatus and Onobrychis crista-galli. These results are similar to those reported by Hanbury et al. (2000), Abdulrazak et al. (2006) and Bakoglu et al. (2009).

On the other hand, the tannin contents of forage legume species were determined to be in high levels in Lathyrus cicera (6.33\%) and in low levels in Trigonella foenum-graceum (0.67\%). In the other forage legumes, the tannin contents were determined as $0.70,0.77,1.63$ and $2.17 \%$ in $L$. leucocephala, O. crista-galli, L. corniculatus and $L$. annuus, respectively (Table 1 ).

Unlike red clover (Trifolium pratense) and Lucerne (Medicago sativa) (Jackson et al. 1996; Wang et al. 1996), lotus (Lotus corniculatus) and sainfoin (Onobrychis viciifolia) contain significant amounts of condensed tannins (Waghorn et al. 1987; Wang et al. 1996). These are polyphenolic secondary compounds that can react by hydrogenbonding with plant protein in the near neutral $\mathrm{pH}$ range to form condensed tannin \pm protein complexes which are insoluble at $\mathrm{pHs}$ found in the rumen, but dissociate below $\mathrm{pH} 3,5$ (Waghorn et al. 1987; Wang et al. 1996). It is now thought that the nutritional role of condensed tannins for ruminants depends on their concentration, structure and molecular weight in plants, and, while high levels of condensed tannins may depress intake and the digestion of protein and fiber (Barry and Manley 1984; Terrill et al. 1992), low levels may increase absorption in the small intestine by reducing rumen protein degradation (Waghorn et al. 1994). Thus, increased animal performance has been documented for sheep grazing lotus compared with sheep grazing non-tanniniferous legumes (Wang et al. 1996).

Table 1

Total protein (\%) and tannin contents (\%) of some forage Legume species from Turkey

\begin{tabular}{lcc}
\hline \multicolumn{1}{c}{ Forage Legume Species } & Protein & Tannin \\
\hline Lathyrus annuus (T-1) & $26.1 \mathrm{c}$ & $2.17 \mathrm{~b}$ \\
Lathyrus cicera (T-2) & $23.1 \mathrm{e}$ & $6.33 \mathrm{a}$ \\
Onobrychis crista-galli (T-3) & $37.2 \mathrm{a}$ & $0.77 \mathrm{~d}$ \\
Trigonella foenum-graceum (T-4) & $24.8 \mathrm{~cd}$ & $0.67 \mathrm{~d}$ \\
Lotus corniculatus (T-5) & $34.0 \mathrm{~b}$ & $1.63 \mathrm{C}$ \\
Leuceana leucocephala (T-6) & $23.9 \mathrm{de}$ & $0.70 \mathrm{~d}$ \\
LSD & 1.4194 & 0.22 \\
\hline
\end{tabular}

Table 2

Fatty acid composition (\%) of some forage Legume species from Turkey.

\begin{tabular}{|c|c|c|c|c|c|c|c|c|c|c|c|c|c|}
\hline \multirow[b]{2}{*}{ Forage Legume species } & \multicolumn{13}{|c|}{ Fatty Acid Components } \\
\hline & $14: 0$ & $16: 0$ & $16: 1 \Delta 9$ & 18:0 & $18: 1 \Delta 9$ & 18: $2 \Delta 9,12$ & $\begin{array}{c}18: 3 \Delta 9 \\
12,15\end{array}$ & 20:0 & $20: 1$ & 22:0 & 24:0 & TSFA & TUSFA \\
\hline Lathyrus annuus & 0.99 & 17.0 & - & 6.69 & 12.04 & 50.0 & 13.30 & 0.11 & - & - & - & 24.68 & 75.45 \\
\hline Lathyrus cicera & 0.50 & 22.2 & - & 2.22 & 27.9 & 12.3 & 29.7 & 0.67 & 0.94 & 1.73 & 0.78 & 24.92 & 74.02 \\
\hline Onobrychis crista-galli & 1.01 & 17.95 & 0.73 & 4.79 & 5.92 & 59.4 & 7.38 & 0.69 & - & - & 0.89 & 24.48 & 74.28 \\
\hline Trigonella foenum-graceum & - & 12.4 & - & 2.66 & 12.0 & 69.5 & 3.46 & - & - & 0.10 & - & 15.06 & 85.06 \\
\hline Lotus corniculatus & 0.76 & 22.03 & 0.64 & 2.53 & 30.52 & 37.06 & 0.89 & 1.28 & 1.12 & 0.66 & 0.75 & 25.96 & 72.28 \\
\hline Leuceana leucocephala & 0.44 & 16.83 & 0.33 & 4.39 & 12.4 & 52.6 & 11.27 & 0.47 & - & 0.74 & 0.57 & 21.99 & 78.05 \\
\hline
\end{tabular}

14:0: myristic acid, 16:0: palmitic acid, 16:1 9: palmitoleic acid, 18:0: stearic acid, 18:1 9: oleic acid, 18:2 9,12: linoleic acid, 18:3 9,12, 15: linolenic acid, 20:0: arachidic acid, 20:1: gadoleic acid, 22:0: behenic acid, 24:0: lignoceric acid, TSFA: Total saturated fatty acid, TUSFA: Total unsaturated fatty acid 
The fatty acid composition of some plants used as feed crops from the Fabaceae family showed different saturated and unsaturated fatty acid concentrations. The main components in the seed oils of feed crops are linoleic, oleic, palmitic and linolenic acids. Analyses showed that low myristic and palmitoleic acid from the fatty acid (FA), and these fatty acids were present at trace levels in the Leguminosae seed oils. Palmitic acid (16:0) was the highest SFA in Lathyrus cicer $(22.2 \%)$, Lotus corniculatus $(22.03 \%)$, Onobrychis cristagalli (17.95\%), Lathyrus annuus (17.0\%), Leuceana leucocephala (16.83\%), and Trigonella foenumgraceum (12.4\%) respectively (Table 2 ). Bagci et al. (2004) reported that palmitic acid was the major component in Trigonella cretica (12.9\%), Lupinus varius $(12.8 \%)$ and Colutea melanocalyx (10.7\%). This is also a very constant lipid constituent in most leguminous genera seed oils. It is possible to say that this fatty acid is not a highly variable component in the leguminous genera pattern. Palmitoleic acid (16:19 was either not detected or detected in very small amounts. Similarly, Trigonella foenumgraceum and Lathyrus annuus had no palmitoleic, gadoleic or lignoceric acid (Table 2).

Stearic acid (18:0) was generally found in low levels, but it was shown in higher concentrations in Lathyrus annuus (6.69\%), Onobrychis cristagalli $(4.79 \%)$ and Leuceana leucocephala (4.39\%). This is also reported for some Vicia sp. from Turkey like V. hyrcanica Fisch. et Mey. (19.4\%), V. peregrina L. (7.3\%), V. hybrida L. (9.1\%) (Akpinar et al. 2001). On the other hand, this fatty acid was reported as lower in some Vicia sp. from different countries; Vicia faba (1.4\%), V. sativa (1.3\%). Colutea melanocalyx and Onobrychis altissima (1.38\% and $1.79 \%$ ) seed oils showed low stearic acid amounts. This FA was reported as $3.1 \%$ in Colutea arborescens (Ivanov and Aitzetmuller 1998). Some researchers indicated that oils with high levels of long chain SFA such as behenic acid may be difficult for the digesting enzymes in humans and animals (Balogun and Fetuga 1985; Akpinar et al. 2001). In addition, Lathyrus cicera had the highest amounts of linolenic and behenic acids (Table 2).

Among the unsaturated fatty acids (USFA), oleic, linoleic and linolenic acids were the major constituents of the studied legume seed oil. The greatest percentages of oleic acid were determined in Lotus corniculatus (30.52\%), Lathyrus cicera (27.9\%), Leuceana leucocephala (12.4\%), Lathyrus annuus $(12.04 \%)$ and Trigonella foenum-graceum $(12.0 \%)$ respectively (Table 2$)$. Trigonella foenumgraceum (69.5\%), Onobrychis crista-galli (59.4\%), Leuceana leucocephala (52.6\%), Lathyrus annuus (50.0\%), Lotus corniculatus (37.06\%), Lathyrus cicera $(12.3 \%)$ showed the highest linoleic acid composition in the seed oils. On the other hand, linolenic acid was determined as the major constituent of the all seed oils of Lathyrus cicera (29.7\%). A high content of this component was found to be characteristic of legume seed oil. The seed oils of all the species analyzed were rich in palmitic acid, stearic acid, oleic acid, linoleic acid and linolenic acid. In the Akpinar et al. (2001) study, while most of the studied Vicia samples showed this result, Vicia hybrid concentrated from the other Vicia taxa. At the same time, oleic and linoleic acids were determined to be the major unsaturated fatty acids in Psophocarpus tetragonnolobus L. (Fabaceae) DC. (Winged bean) oil which is used as a food in the diets of some countries (Higuchi et al. 1982).

The total saturated fatty acid (TSFA) concentrations of the oils were between $15.06 \%$ and $25.96 \%$. Total unsaturated fatty acid (TUSFA) contents were found between 72.28 and $85.06 \%$. Linoleic, oleic and linolenic components were reported as the main TUSFA components in Lathyrus (Grela and Gunter 1995; Bagci et al. 2001), Colutea, Gonocytisus, Lupinus, Vicia, Hedyserum, Onobrychis, Trigonella (Bagci et al. 2004) and Astragalus (Bagci and Vural 2001; Bagci 2006) genera patterns and also in some other family patterns like Euphorbiaceae (Bagci, 2007). The high TUSFA contents in these seed crops have nutritional significance.

The results of the present study, as far as unsaturated fatty acid content is concerned, is supported by previous leguminous studies (Sengupta and Basu 1978; Daulatab et al. 1987; Tharib and Veitch 1983; Hamberg and Fhalstadius 1992; Liu et al. 1995). All these studies showed that the saturated and particularly unsaturated FA contents of Fabaceae seed oils are closely allied to each other and the main components in the oils are linoleic-oleic type fatty acids.

In general, legumes occupy an important place in human and also animal nutrition. Legumes are rich in proteins and complex carbohydrates and are important sources of minerals and vitamins (Mahadewamma and Tharanathan 2004). Grain legumes are potential sources of energy and micronutrients but their application is still limited because of uncertainty about the amount and the effect of antinutritional factors they may contain (Wiryavan and Dingle 1999).

\section{CONCLUSIONS}

The oil contents of the studied legumes belonging to the Lathyrus, Onobrychis, Trigonella, Lotus, and Leuceana genus, showed quantitative differences but the seed oils showed uniform fatty acid compositions. The seed oils of the all the investigated species were rich in palmitic acid, stearic acid, oleic acid, linoleic acid and linolenic acid. In the Akpinar et al. (2001) study, most of the studied Vicia samples showed the same results as ours. The results revealed that the seed oils of Lathyrus, Onobrychis, Trigonella, Lotus, and Leuceana patterns studied with a substantial amount of very long chain fatty acids might have attracted attention because of their value as nutritional, industrial and renewable resources. 


\section{REFERENCES}

Abdulrazak SA, Kahindi RK, Muinga RW. 2006. Effects of Madras thorn, Leuceana and Gliricidia supplementation on feed intake, digestibility and growth of goats fed Panicum hay. Livestock Res. Rural Develop., 18, 124-128.

Akpinar N, Akpinar MA, Turkoglu S. 2001. Total lipid content and fatty acid composition of the seed of some Vicia L. species. Food Chem., 74, 449-453.

AOAC, 1990. Official Method of Analysis. 15th. edn. Association of Official Analytical Chemist, Washington, DC. USA.

Bagci E, Bruehl L, Aitzetmüller K, Altan Y. 2004. Fatty acid and tocochromanol patterns of some Turkish Boraginaceae. Nordic J. Bot., 22, 719-726.

Bagci E, Bruehl L, Aitzetmuller K, Altan Y. 2003. A Chemotaxonomic Approach on the Fatty Acid and Tocochromanol Content of Cannabis sativa L. (Cannabaceae). Turkish J. Bot., 27, 141-147.

Bagci E, Genc H, Sahin A. 2001. Fatty acid composition of four Lathyrus aphaca L. varieties. A chemosystematic approach. Pakistan J. Bio., 4, 842-874.

Bagci E, Vural M. 2001. Fatty acid composition of Astragalus pycnocephalus var. pycnocephalus and Astragalus condensatus, a chemotaxonomic approach. J. Inst. Sci. Technol. Gazi Univ., 14, 1305-1311.

Bagci E. 2006. Study of fatty acid patterns of some Astragalus L. (Fabaceae) species from Turkey. Chem. Nat. Prod., 42, 645-648.

Bagci E. 2007. Fatty acid and tocochromannol patterns of two Euphorbia L. (Euphorbiaceae) species. Int. J. Sci. Technol., 2, 93-98.

Bakoglu A, Bagci E, Ciftci H. 2009. Fatty acids, protein contents and metal composition of some feed crops from Turkey. J. Food Agric. Environ., 7, 343-346.

Balogun AM, Fetuga BL. 1985. Fatty acid composition of seed oils some members of the Leguminosae family. Food Chem., 17, 175-182.

Barry TN, Manley TR. 1984. The role of condensed tannins in the nutritional value of Lotus pedunculatus for sheep. 2. Quantitative digestion of carbohydrates and protein. Br. J. Nut., 51, 493-504.

Basaran U, Acar Z, Asci OO, Mut H, Ayan I. 2007. Agricultural importances, using possibilities and toxic substances of Lathyrus species. J. Fac. Agric., OMU. 22, 139-148.

Broca C, Gross R, Petit P, Sauvaire Y, Manteghetti M, Tournier M, Masiello P, Gomis R, Ribes G. 1999. 4-Hydroxyisoleucine: experimental evidence of its insulinotropic and antidiabetic properties. Am. J. Physiol., 277, 617-623.

Christie WW. 1990. Gas Chromatography and Lipids: A practical guide. The Oily Press, Ayr, pp. 307.

Dalzell SA, Stewart JL, Tolera A, McNeill DM. 1998. Chemical composition of Leucaena and implication for forage quality. In: H.M. Shelton, R.C. Gutteridge, B.F. Mullen \& R.A. Bray (eds). Leucaena-Adaptation, quality and farming systems. Vol. 86 ACIAR. Canberra, pp. 227-246.

Daulatab CD, Hosamani KM, Deasi VA, Alagawadi KR. 1987. Cyclopropenoid fatty acids in Leguminosae oils. JAOCS 64, 1423.

Grela E R, Gunter KD. 1995. Fatty acid composition and tocopherol content of some legume seeds. Animal Feed Sci. Technol., 52, 325-331.

Hamberg M, Fahistadius P. 1992. On the specificity of a fatty acid epoxygenase in broad bean (Vicia faba L.). Plant Physiol., 99, 987-995.
Hanbury CD, White CL, Mullan BP, Siddique KHM. 2000. A review of the potential of Lathyrus sativus $L$. and $L$. cicera L. grain for use as animal feed. Animal Feed Sci. Technol., 87, 1-27.

Hara A, Radin NS. 1978. Lipid extraction of tissues with a low toxicity solvent. Anal. Biochem., 90, 420-436.

Higuchi M, Terao J, Jwai K. 1982. Gas ChromatographyMass Spectrometric determination of winged bean (Psophocarpus tetragonolobus (L.)DC.) J. Nut. Sci. Vit. 28, 511-518.

Ivanov SA, Aitzetmuller K. 1998. Undersuchungen über die tocopherol-und-tocotrienol Zusammensetzung der samenlipide einiger arten der Bulagarischen Flora. Fett. Lipid 100, 348-352.

Jackson FS, McNabb WC, Barry TN, Foo YL, Peters JS. 1996. The condensed tannin content of a range of subtropical and temperate forages and the reactivity of condensed tanin with ribulose-1,5-bisphosphate carboxylase (Rubisco) protein. J. Sci. Food Agric. 72, 483-492.

Krishna AG, Prabhakar JV, Aitzetmuller K. 1997. Tocopherol and fatty acid composition of some Indian pulses. JAOCS 74, 1603-1606.

Liu K Brown EA, Orthoefer F. 1995. Fatty acid composition within each structural part and section of a soybean seed. J. Agric. Food Chem. 43, 381-383.

Lu Y, Sun Y, Foo LY, McNabb WC, Molan AL. 2000. Phenolic glycosides of forage legume Onobrychis viciifolia. Phytochemistry 55, 67-75.

Mahadewamma S, Tharanathan T. 2004. Processing of legumes. Resistant starch and dietary fiber contents. J. Food Qual. 27, 289-303.

Makkar HPS, Blümmel M, Becker K. 1995. Formation of complexes between polyvinylpolypyrrolidone or polyethylene glycols and tannins and their implication in gas production and true digestibility in vitro techniques. Br. J. Nut. 73, 897-913.

Mangan JL. 1988. Nutritional effects of tannins in animal feeds. Nut. Res. Rev., 1, 209-231.

Norton BW. 1994. Antinutritive and toxic factors in forage tree legumes. Tropical Tree Legumes in Tropical Agriculture. CAB International, pp 202-215.

Petit $P$, Sauviaire $Y$, Hillaire-Buys DM, Leconte OM, Baissac YG. 1995. Steroid saponins from fenugreek seeds: Extraction, purification, and pharmacological investigation on feeding behavior and plasma cholesterol. Steroids 60, 674-680.

Sengupta A, Basu S. 1978. Trygliseride composition of Enteda phasolides seed oil. J. Am. Sci. Food Agric. 29, 677-682.

Terrill TH, Rowan AM, Douglas GB, Barry TN. 1992. Determination of extractable and bound condensed tannin concentrations in forage plants, protein concentrate meals and cereal grains. J. Sci. Food Agric. 58, 321-329.

Tharib SM, Veitch GBA. 1983. The fatty acids of Phaseolus coccineus and Gleditsia triacanthos (Family: Leguminosae). Int. J. Crude Drugs Res. 21, 73-77.

Waghorn GC, John A, Jones WT, Shelton JD. 1987. Nutritive value of Lotus corniculatus L. containing low and medium concentrations of condensed tannins for sheep. Proceed. N.Z. Soc. Animal Prod. 47, 25-30.

Waghorn GC, Shelton ID, McNabb WC. 1994. The effect of condensed tannin in Lotus pedunculatus on nutritive value for sheep 2 . Nitrogenous aspects. J. Agric. Sci. (Camb.) 123, 109-119.

Waghorn GC, Shelton ID. 1992. The nutritive value of lotus for sheep. Proceed. N.Z. Animal Prod. 52, 89-92. 
Wang Y, Douglas GB, Waghorn GC, Barry TN, Foote AG, Purchas RW. 1996. Effect of condensed tannins upon the performance of lambs grazing Lotus corniculatus and lucerne (Medicago sativa). J. Agric. Sci. (Camb.) 126, 87-98.
Wiryavan KG, Dingle JG. 1999. Recent research on improving the quality of grain legumes for chicken growling. Animal Feed Sci. Technol. 76, 185-193.

Recibido: $3 / 12 / 10$ Aceptado: $3 / 3 / 11$ 